\title{
Common Features between the Cham Dialect and Other Albanian Dialects
}

\author{
Msc. Entela Kore \\ “Eqrem Çabej” University, Gjirokastër, Department of Albanian Language, Albania
}

*Corresponding Author: Msc. Entela Kore, "Eqrem Çabej" University, Gjirokastër, Department of Albanian Language, Albania

\begin{abstract}
The Cham dialect is a peripheral dialect of the Albanian language which preserves old forms of words. These old forms and features are reminiscent of the early stages of the Albanian language. They can be found in the writings of most original writers of the Albanian language and literature and in the Arbëresh dialects in Greece and Italy.

In this section we will deal with some similar phenomena between the Cham dialect and other Albanian dialects. By comparing this dialect with other dialects of the southern Tosk dialect group like the Gjirokastra dialect, Muzina dialect, the Lower Riviera dialect, and the Kurvelesh dialect we can give a full picture of similarities and common occurrences among these dialects. 1

Gjirokastra dialect approximates to the Cham dialect even in the retention of the old intervocalic $l$ that derives from $l j$. In the Gjirokastra dialect we encounter this intervocalic $l$ in words such as: milë, bilë, malë (majë), golë; as part of the suffix - ëla- which forms verbal nouns: nisëla, ardhëla, ngrënëlal; as a suffix which forms feminine nouns deriving from their masculine counterparts dajkëla, Mezanëla, Hasanëla. Another dialect which is also similar to the Cham dialect is the Muzina dialect. The first feature we would like to highlight is the pronunciation of the stressed vowel e. In this dialect, this vowel before the nasal consonants $m, n$ and $n j$ has been transformed into $\ddot{e}$ in the same way as in the Cham dialect, but unlike the Cham dialect and other dialects of the South $\ddot{e}$ in this dialect it feels as being more front in the words: zëmër, fëmër, shtrëmbër, thëmër etc,. By analogy with this, the vowel $\ddot{e}$ has been added in some other cases that do not contain nasal consonants: strëhë, flë dhe plëhë.
\end{abstract}

Regarding the other dialects, we would like to say a few words about some features common to the Cham dialect, to the Lab dialect or Kurveleshi dialect. Of interest are the similarities in the field of vowels. Here we stress the long vowels, which are equally stressed like in the Cham dialect: shtëpi:, dru:, the:, vu:, shpu: ; ba:r, va:rr, bi:r; de:t, ka:l, uri:th.

The last dialect we will talk about, which is similar to the Cham dialect is the Lower Riviera dialect. The similarities here are also worth mentioning.

Keywords: The Cham Dialect, Features, Stress, Assimilation, The Lab Albanian Dialect, Muzina.

\section{INTRODUCTION}

In this section we will deal with some similar phenomena between the Cham dialect and other Albanian dialects. By comparing this dialect with other dialects of the southern Tosk dialect group like the Gjirokastra dialect, Muzina dialect, the Lower Riviera dialect, and the Kurvelesh dialect we can give a full picture of similarities and common occurrences among these dialects.

\section{DisCUSSION}

1.First, we deal with Gjirokastra dialect, with which the Cham dialect shows the most significant similarities. The first feature we will point out between the two dialects is word stress. Words in Gjirokastra dialect of Turkish and Greek origin retain the stress of the language from which they were borrowed. ${ }^{1}$. Thus, in the Gjirokastra and in the other Southern dialects, stress falls on the final syllables in the words: mashá, futá, jaká, odá, sufrá. ${ }^{2}$ The same phenomenon can be seen in the Cham

\footnotetext{
${ }^{1}$ M. Totoni, Vëzhgime rreth qytetit të Gjirokaastrës, SF, nr.1, 1966, p. 81.

${ }^{2}$ M.Totoni, article cited above , p. 81
} 
dialect: dushemé, kavé, xhepané, hamilé, llapá, sufrá, bojá, mashá. But in this dialect the above mentioned nouns are treated as masculine, thus we find sufrái, mashái, kasabau, hajmaliu ${ }^{3}$. Even in Pedersen we find the same form: vunë dhe bukën arrotulla sufráit ${ }^{4}$. What we find interesting in this dialect which is also found in the Cham dialect, is the lack of phoneme $y$ and the presence of the phoneme $u$ in its place: $k i$, ill, indirë, zirë, natirë, mbit, grikë; dallandushe, gjukatës ${ }^{5}$.

Gjirokastra dialect approximates to the Cham dialect even in the retention of the old intervocalic $l$ that derives from $l j$. In the Gjirokastra dialect we encounter this intervocalic $l$ in words such as: milë, bilë, malë (majë), golë ; as part of the suffix ëla which is used in forming verbal nouns: nisëla, ardhëla, ngrënëla ${ }^{6}$; as a suffix which forms feminine nouns deriving from their masculine counterparts dajkëla, Mezanëla, Hasanëla

In the Cham dialect like in the Gjirokastra dialect, the consonant clusters $l k$ and $l g$ have been retained in the words: alkë and balgë. The pronunciation of these words with the $l k$ group has remained unchanged in these dialects. In Gjirokastra dialect we have: bulk, ulqre; ${ }^{7}$ in the Cham dialect: ulkë, alkë, balgë.

In the verbal system, a feature common to the Cham and the Gjirokastra dialects is the retention of the inflectional suffix $c ̧$ in the present tense of the subjunctive and optative mood: ruaç, thaçë, paçë; të duaç, të març, të hedhç; vafça, prufça, vufça. ${ }^{8}$

Another feature that we would like to emphasize here is the retention of consonant $r$ in the word palë / parë, which here is not transformed into $l$ as it happens in other dialects. This phenomenon is still found today, especially among the elderly: i mora një par vath të bukur $(\mathrm{Gjr})$. As regards pronouns in this dialect stands out the retention of the old form of the personal pronoun unë, in Gjirokastra it is always found in the form $u$ : $u$ të thom kështu ti më thua katra putra / të thom $u ́$ ku t e gjesh. Another feature common to the two dialects is the transformation of stressed $e$ into $\ddot{e}$ before the nasals in some words: dëm, ëngjëll, brënda, gjëndje, $i$ çmëndur ${ }^{9}$ etc. But the opposite happens with the word enjtur 'jam enjtur' where stressed $e$ at the beginning of the word is replaced by $a$, thus we find, jam ajtur. ${ }^{10}$

Even some phonetic phenomena are similar in these two peripheral dialects. From the Cham dialects we can bring some examples from the research conducted by Q. Haxhihasani ${ }^{11}$ on the assimilation of rrn into rr: beharrë, haberrë, të birrë, manarrë, varrë, zjarrë, u therrë, hëngërrë, muarrë; In Gjirokastra dialect: Sa qava për beharë, s'qava për babanë (saying); Hatërë e kemi borxhe; Ajo të fut zjarrë. Hir e dil e tund peshqirë. (riddle) ${ }^{12}$

As to the assimilation of $l l n$ into $l l$ this scholar brings the examples: puallë, suallë, vuallëdhn $>d h: u$

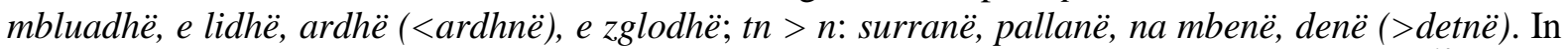
Gjirokastra dialect it is found in the expressions: S'njeh qeni të zonë; Është përmbi mbrenë ${ }^{13}$. There are similarities even in the assimilation of the ssh group into $c$ in inflectional endings. In the Cham dialect, this phenomenon is found in such words as: të nglaç, të pjeç, të flaç. ${ }^{14}$ The same phenomenon is noticed in Gjirokastra dialect. The assimilation of $t s h$ into $c ̧$ : In Cham dialect, $i$ mënçim, i nderçim, fjeç, arç. In Gjirokastra: Vafç e arç mirë; E do të nderçme, e do punëtore.

Another phenomenon common to the two dialects is the retention of the final vowel $\ddot{e}$ in proparoxytone words and some other forms, although it should be said that this is a disappearing phenomenon along with the elderly. In the old Cham dialect we find : kartëratë, dhëndërinë, të

\footnotetext{
3 Q.Haxhihasani, Vështrim i përgjithshëm mbi të folmen e banorëve të Çamërisë, DSH, 1, Tiranë, 1971, p. 161

${ }^{3}$ M.Totoni, cited article., SF, 1966, p. 98.

${ }^{4}$ H. Pedersen, Albanesische Texte, mitt glosar, Leipzig, 1895, p.

${ }^{5}$ M.Totoni, cited article., SF, nr.1, 1966, p. 87.

${ }^{6}$ Q. Haxhihasani, cited article., DSH I, p. 132.

${ }^{7}$ M. Kore, "Gjirokastra vështrim historik, gjuhësor, etnologjik", Tiranë, 2014, p.121.

${ }^{8}$ Q. Haxhihasani, cited article., DSH I, p.106

${ }^{9}$ The same place, p. 82

${ }^{10}$ This form is the same in the Cham dialect, which is used in this from.

${ }^{11}$ Q. Haxhihasani, cited book., p. 156.

${ }_{12}$ M. Kore, "Gjirokastra vështrim historik, gjuhësor, etnologjik", Tiranë, 2014, p. 122.

${ }^{13} \mathrm{M}$. Kore, the same place, p. 123.

${ }^{14}$ Q. Haxhihasani, DSH I, p. 183.
} 


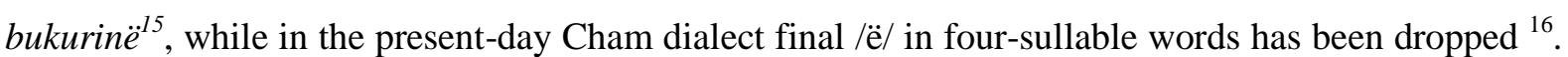
In Gjirokastra, according to M. Kore ${ }^{17}$ we find : fjálëtë, bíshtratë, këmbëtë, kóshtratë, nëmatë, úmërinë. Even in M. Totoni research we find the following words: fundratë, koshtinë, zemrënë, lëkurënë, nusenë etc. ${ }^{18}$

In morphology, these two dialects are quite similar regarding the formation of the plural forms of the present tense, first person and third person plural, by taking on the inflectional endings: v. I -im, III in and v. I - ëm and III - ën. Consonant-stem verbs take on these inflectional endings: : krip-im, kripit, krip-in; dredh-im, dredh-it, dredh-in, vras-im, vras-it, vras-in. ${ }^{19}$ The inflectional endings - ëm and $\ddot{e} n$ are rarely encountered in this dialect, moreover, these inflectional endings are found in the Kurveleshi dialect as the only means to form the plural number: përdorëm, qethëm, flasëm, dalën, and so on. In the Cham dialect -im, -ni and -in are among the most widespread inflectional endings where the first and third person plural approximate to the Gjirokastra dialect: goditim, goditni, goditin, këputim, këputni, këputin. Concerning the use of the infelctional endings -ëm and -ën in the Cham dialect we bring the examples: pjesëm, pjesni, pjesën, presëm, prisni, presën, vrasëm, vrisni, vrasën. As a result of the evolution of the Cham dialect, these inflectional endings have been replaced by -im and $-i n$. The inflectional endings - $\ddot{e} m$ and $-\ddot{e} n$, in this dialect have been used by the elderly, thus having a more limited spread.

Neutral gender is another feature common to both dialects. In the Gjirokastra dialect it is retained in some nouns that show substance and some verbal nouns: u haej misht / ngjeshësh brumët / dhjamët $\mathrm{e}$ dashit; të lindurit / të ngrënët / të ngrohëtit etj. ${ }^{20}$ In the Cham dialect we have: gjalqët, djathët, misht e pelisterit haet, më diq kriet, ballt e këmës, u sëmurë ka të ftohtët.

Since we are talking about morphology, we should say that the formation of the plural from of the words djale and kalë is of interest because they show the same form as they do in Gjirokastra dialect, their respective plural form being djelm and kuel. The plural genitive and dative case in both dialects retain the old form without the epenthetic $v^{21}$; thus in the Cham dialect we have: në dasmë të djelmet / kështu u thomi monjet neve / u thonë nipëret... ${ }^{22}$... in Gjirokastra dialect we have: për kokën $\mathrm{e}$ djemet / jau shpinin miqet / damarët e duare. ${ }^{23}$

In addition to these, there are also some prefixes and suffixes common to both dialects. From the prefixes we would single out those of Greek origin ${ }^{24} k s e$ - and kako. Thus in Gjirokastra we hear: $e$ ksebëra, ksebëj, kakoduket, më kakovjen ${ }^{25}$; while in the Cham dialect we have: do ti ksebëj këta dhëntë/ më kakoduket. ${ }^{26}$. While common suffixes are: - atë, -anj -eshë, -e, -ra. Examples with these suffixes in Gjirokastra would include the patronyms: Zekatë, Karagjozatë, Sinomeratë; Hadëranj, Koranj, Shtinanj; mufti-muftesha, dollape, tavane, çengele, kazane; fundëra, frikëra, punëra etc.

Apart from the similarities we mentioned above, both dialects have a significant number of common words of their daily lexicon, with the same sound features. Many of them are Greek borrowings, but there are also Turkish ones, such as: ksehas, skalis, potis, kalistirë, kazma, futá, sufrá, vjoli, sallamur, cuks, cingris, proftas, feste, bolori, skuri, makar etc,.

2.The second dialect which is also similar to the Cham dialect is the Muzina dialect. From the dialect point of view, Muzina dialect has similar features to the Konispol dialect, which is made up of the Cham-speaking community, but at the same time it is also similar to the Gjirokastra and Delvina dialects. The first feature we would like to highlight is the pronunciation of stressed vowel $e$. In this dialect, this vowel has been transformed into $\ddot{e}$ before the nasal consonants $m n$ and $n j$ in the same

\footnotetext{
${ }^{15}$ Q. Haxhihasani, cited article., DSH I, p. 144, cited according to Pedersen.

${ }^{16}$ The same author, the same place .

${ }^{17}$ M. Kore, the same place. p. 106

${ }^{18}$ Shih; M.Totoni, Vëzhgime rreth të folmes së qytetit të Gjirokastrës, SF, Nr. 1, 1966, p. 82-83

19 The same place, p. 101

${ }^{20}$ The same place, p. 94 .

${ }^{21}$ We have mentioned this feature before in Tipare të përbashkëta mes çamërishtes dhe autorëvë të vjetër.

${ }^{22}$ Q. Haxhihasani, Vështrim i përgjithshëm mbi të folmen e banorëve të Çamërisë, DSH, 1, Tiranë, 1971, p. 169

${ }^{23}$ M.Totoni, cited article, SF, 1966, p. 98.

${ }^{24}$ Q. Haxhihasani, cited article, DSH, 1, Tiranë, 1971, p. 132

${ }^{25}$ The same place, 132.

${ }^{26}$ Q. Haxhihasani, cited article, DSH, Vëll II, Tiranë, 1974.
} 
way as in the Cham dialect, but unlike the Cham dialect and other dialects of the South ${ }^{27}, \ddot{e}$ in this language feels as being more front in the words: zëmër, fëmër, shtrëmbër, thëmër etc. By analogy with this, the vowel $\ddot{e}$ has been added in some other cases that do not contain nasal consonants: strëhë, flë dhe plëhë. ${ }^{28}$

Another phenomenon common to the two dialects is the pronunciation with the vowel $\ddot{e}$ of some words that in other dialects are pronounced with a: $i$ ëmbël, këmbë, kam lënë, kam zënë etj.

Of interest is the pronunciation with the vowel $a$ of the word enjtur in the two dialects, this word has retained the form ajtur ${ }^{29}$ qe ajtur e qe buavitur nga fitira. ${ }^{30}$

The unstressed final vowel $\ddot{e}$, in most words has been dropped, but here we encounter it in the participles of some verbs: lidhurë, veshurë, kapurë; in some nouns in the accusative case: natënë, furkënë, tjetrënë, kokënё $\ddot{e}^{31}$ like in the Cham dialect.

Another feature common to the two dialects is the lack of phoneme $y$. Thus: di, dill, ill, tim, shtip, si, $a t i^{32}$ are some of the words which have the phoneme $i$ instead of $y$. In some cases, we also encounter words with the vowel $u$ : burek, gjuna, shuqur, words which are also present in the Cham dialect. Likewise, the vowel $i$ is present in the vocalic cluster ye just like in the Cham dialect: dier, liej and thiej. In this dialect, the verb pyes is realized with the stressed vocalic cluster ie, pies, like in the Cham dialect: pieta, pjeti, më pietnë.

In addition to the similarities we mentioned regarding vowels, common features are found regarding consonants. In the consonant system a phenomenon common to these two dialects is the transformation of the consonant $q$ into $j$ in words like: mijtë, plejtë, fijte ${ }^{33}$. In fact, this phenomenon is more reduced in Muzina dialect than it is in the Cham dialect in which forms with the palatal $q$ are more dominant.

The consonant $z$ at the beginning of the words beginning with $b, g, g j$ and $v$ has been transformed into the affricate $x$, a phenomenon that often occurs in the Cham dialect obtaining special forms of words: xuarr, xbut, xirgu for zbrit, xbath. Even in Muzina dialect, we see the same phenomenon for the words: xbut, xbuloj, xbath, zjebe "zgjebe".

Another similarity between these two dialects is the retention of the consonant clusters: $\mathrm{kl} \mathrm{e} \mathrm{gl}$ : $\mathrm{klaj}$, glisht, klumusht, $i$ glatë, glëmb, gluri, zglidh. However, the pronunciation of these clusters is on their way out. Among the last consonant clusters that are common to the two dialects, we can mention the group $l k$ : ulk e bulk; which like in the Cham dialect, has limited currency and it is mainly used by the elderly.

Regarding the phonetic phenomena, we would single out the phenomenon of assimilation, through which the same forms like in the Cham dialect have been obtained. The phenomenon of assimilation in the Muzina dialect has affected the words: mbuallë, duallë, zjarrë > zjarrnë, mallë > mallnë, mbemë > mbetmë etj. ${ }^{34}$

A part of the nouns of this dialect have the same forms as in the Cham dialect. Thus, neutral gender is a feature common to the two dialects, which has been retained in some nouns that show substance: gjalpëtë, djathtë, mishtë, ujëtë. But in terms of their use today, we can say that these nouns are also disappearing and are ever more treated as masculine gender nouns ${ }^{35}$. The nouns sufrai and mashai have also been used in the masculine gender, like in the Cham dialect.

A lot of desinential suffixes of the plural are common to both dialects like: $-n j$, $-e$, and -ra; glunj, hunj, priftërinj, qilare, kazane, punëra, copëra. The noun kalë has the same plural form. In this dialect, its plural form is the same as the Cham dialect kual dhe kueltë.

\footnotetext{
27 The dialect of Kurveleshi and Lower Riviera.

${ }^{28}$ M.Totoni, Vëzhgime për të folmen e Muzinës, “SF”, 3, 1965, p. 103

${ }^{29} \mathrm{We}$ see this feature also in the Gjirokastra dialect.

${ }^{30}$ This phenomenon is seen also in the Gjirokastra dialect ; in this dialect apart from the common form that we mentioned, anjtur / enjtur, there is also the pronunciation with the vowel $a$ for the verb ha: hangri, $i$ hangër, të hangërt.

31 Cited article above. p. 104

32 The same place, p. 104

${ }^{33}$ The same place, p. 105

${ }^{34} \mathrm{M}$. Totoni, article cited above. p. 106

${ }^{35} \mathrm{M}$. Totoni, The same place, p. 107
} 
Regarding the nouns in the genitive and dative cases we notice the same phenomenon regarding both the Cham dialect and the Gjirokastra dialect. In Muzina dialect nouns in genitive and dative plural do not get the epenthetic $v$, but instead have the inflectional ending $e$ : do t' ua jap djemet, $c^{\prime}$ ' thoshin pleqet, fukarenjet etj. ${ }^{36}$ Of the adjectives which show similarity regarding the way their plural form is formed we would single out the forms: $i$ glatë-të gletë and $i$ trashë- të treshë.

However, meeting points regarding the verbs kam, jam e them, which in the imperfect have the form keshe, jeshe, keshmë, also exist. Even the compound tenses of verbs display the same phenomenon as in the Cham dialect. The passive, reflexive and middle diathesis of these verbs is formed by the auxiliary verb kam, adding the particle $u$ : In the Cham dialect: $u$ ka thier, $u$ ka prrishur, $u$ kam rritur $n \ddot{e}$ Margëlliç, ${ }^{37} u$ kishin bënë si mos më keq; in the Muzina dialect: $u$ kish martuar di herë, $u$ kish bënë një luftë nji herë, m'u ka prerë gjaku, $u$ kam ftohur sonde natën. ${ }^{38}$ The inflectional ending $c$ for the forms of the sigmatic aorist and the subjunctive is rarely encountered in this dialect, however, unlike the Cham dialect.

Regarding the use of prepositions, we mention the preposition ne of the nominative case, which is used instead of the preposition $t e: n e$ ai djali, $n e$ bithe fikut. ${ }^{39}$

As regards word-formation the presence of the suffix $-\ddot{e} l$ and imtë is common to both these dialects. The suffix $-\ddot{e} l$ is attached to the verbal stems thus obtaining the words: plasël, vdekël, mbrojtël; with the suffix -imtë the adjective $i$ forimtë is formed by the noun fori.

3. Regarding the other dialects, we would like to say a few words about some features common to the Cham dialect, to the Lab Albanian dialect or Kurveleshi dialect. Of interest are the similarities in the field of vowels. Here we stress the long vowels, which are equally stressed like in the Cham dialect: shtëpi:, dru:, the:, vu:, shpu: ; ba:r, va:rr, bi:r; de:t, ka:l, uri:th. ${ }^{40}$

From our recordings and research on the language of Cham-speaking people settled in the city of Vlora, we can say that the vowels of certain words, whether open or closed ones, carry a special emphasis. This is a feature common to both dialects whose presence should be stressed, despite the fact that the Lab Albanian dialect has affected the speech of Cham-speaking people, making these vowels feel even longer than usual: e. g. ai ishte i ri::, ai është njeri:: në radhë të parë / edhe prindërit e mi:: më kanë ikur të ri:: / ki:: më ka ardhur në shtëpi:, të di: vinin nga familje mi:r / i kam thë:n kam $b \ddot{e}: r$ edhe u punëra të tilla / kam uri: etc,.

Regarding the use of vowel $i$ instead of $y$ we can say that there are some differences. A part of Kurveleshi region retains the pronunciation with $y$ while the rest is inclined to pronounce words with the vowel $i{ }^{41}$ In general, for words of Turkish origin we have the vowel $u$ : burek, dushek, dufek, dunja; in Kuç e Çorraj there exist the same forms as in the Cham dialect: di, atire, dill, fit, grik, ill, zir etj. ${ }^{42}$

Regarding the consonant system we point out the consonant $q$, which before the syllabic consonants $m$ and $n$ and before the dental $t$ has transformed into $j$ just like in the Cham dialect: hojmë "hoqmë", po:jm "poqmë" ndrejnë "ndreqnë", zojtë "zoqtë". ${ }^{43}$ In Pedersen we find: edhe e vunë çobanëtë edhe e pojnë...(Alb.texte, f. 79).

The other feature common to both dialects is the transformation of the consonant $z$ into the fricative $x$ before the voiced $b$ and $v$ : xbath" "zbath", xbut "zbut", xerk "zverk" xarr "zvarr".

As far as the phonetic phenomena are concerned, both dialects are rich in assimilation, whether full or partial. Among the partial assimilations in the field of consonants, we mention: hamnë ( $<$ hapnë), himn (< hipnë), qemn (< qepnë), ign (< iknë), fign ( < fiknë). Regarding full assimilation we would single out: imë $\left(<\mathrm{ikmë)}\right.$, primë $\left(<\right.$ pritmë), kullom (< kullotmë) etc,. ${ }^{45}$

\footnotetext{
${ }^{36} \mathrm{M}$. Totoni, The same place, p. 107

${ }^{37}$ Q. Haxhihasani, cited article., DSH I, p. 186

${ }^{38}$ M. Totoni, cited article., SF, I, p. 114

${ }^{39}$ The same place, p. 115

40 M. Totoni, Vëzhgime rreth të folmeve të Kurveleshit, DSH I, Tiranë, 1971, p. 40- 41.

${ }^{41}$ For more details concerning this phenomenon see M. Totoni, article cited above, p. 46

42 The same place, p. 46

${ }^{43}$ The same place, p. 48

${ }^{44}$ For this word there is also the form xath.

${ }^{45}$ Article cited above, p. 55.
} 
These are some of the similarities in the field of vowels and consonants. Of interest are also some similarities in the field of pronouns. In the Lab Albanian dialect the forms of singular and plural personal pronouns unë and ne always have the form $u$ and na: sikur kam vështruar $u / u$ e ti / si të bëj $u$ bëni dhe ju. In the Cham dialect the personal pronoun in the nominative case first person singular always has the form $u$ : di $u$ i shkreti, ç' do kem $u$, edhe $u$ të dua, $u$ e pjeta, s'i thom më $u$, le të bëjë si të det. The form ne is regularly used in the first person plural in this dialect: do vime edhe neve, kështu u thomi monjet neve. ${ }^{46}$

There are also some verbal forms that are the same in these two dialects. Thus, the short form of the third person singular of the imperfect of the verbs bënte, vinte, kërkonte, ${ }^{47}$ in this dialect are: bën, vin, kërkon the same as in the Cham dialect. The verb vete, in this dialect retains the same form as in the Cham dialect vate: vate pru / vate e shpu. ${ }^{48}$

Also, regarding the verbal system, we should emphasize the inflectional ending of the subjunctive which here like in the Cham dialect, has the same form ç: të punoç, të zëç, të shoç, të shkruaç, të preç etc.,

4. The last dialect we will talk about, which has similarities with the Cham dialect is the Lower Riviera dialect. This also has some similarities worth mentioning.

First, in the vowel system there is no phoneme $y$ in this dialect and the words which contain this phoneme, like in the Cham dialect are pronounced with the vowel $i$ : grikë, pasqirë, si, ki, për tia, dizet, ndrishoj etj ${ }^{49}$. In some words we see the presence of the phoneme $u$ instead of the vowel $i$ : burek, dufek, dusheme, musafir, gjum "gjym" 50.

Among the vocalic clusters, we would like to single out ye, which in this dialect retains the form ie like in the Cham dialect. As a vocalic cluster we encounter it in the words: liej, thiej, ngjiej and krie. The verb pyes in this dialect is realized mostly with the vocalic cluster or with the diphthong in some cases: pieta, pies, pjete, pa pjem mua. ${ }^{51}$

In the consonant system common to these two dialects is the transformation of $q$ into $j$. The consonant $q$ is transformed into $j$ before the consonants $t, m, n$ : armijt, të lijt, vdijnë, plejt, zojt, ndrejn, u pojnë etc,.

Another phenomenon common to these two dialects is the transformation of the consonant $z$ into the affricate $x$ either as a simple sound or as a prefix $(\mathrm{z}>\mathrm{x})$ : xath "zbath", xerku "zverku", xarr "zvarr". In addition to the similarities between the vowels and consonants, we would like to mention the phenomenon of assimilation, which in this speech is not as frequent as in the Cham dialect and other Tosk dialects. Some words that feature partial consonantal assimilations are: imni $(<$ ipni), hamnë $(<$ hapnë), duall (< dullnë), muar (<muarnë), këpunë (< këputnë). ${ }^{52}$

Another phenomenon is the similarity between some verbal forms. The auxiliary verbs kam and jam in the imperfect have the same forms like in the Cham dialect: kesh, keshe, kish, keshëm, keshët, keshët; jesh, jeshe, ish, jeshëm, jeshët, jeshën. Of interest here is also the verb dal, which in the present perfect has the same form as in the Cham dialect: dolla, dolle, dolli, duallm, duallt, duall ${ }^{53}(<$ duallnë).

Another feature common to the two dialects is the inflectional ending that verbs in the subjunctive get. In this dialect, the verbs that end in a vowel or a consonant, in the present tense second person singular, get the inflectional ending $c$ like in the Cham dialect: të japç, të thuaç, të marrç, të zëç, të shkruaç etcj,. Even the forms of the verbs kam, jam, dua and thom, are the same as in the Cham dialect: të ket, të jet, të det and të thet.

\section{CONCLUSION}

These were, in general, some of the similarities between the Cham dialect and other dialects of our language. In this context, it is worth pointing out that the Cham dialect is the only sub-dialect of our

\footnotetext{
${ }^{46}$ Q. Haxhihasani, cited article., DSH I, p. 172

${ }^{47}$ Q. Haxhihasani, cited article., DSH I, p. 131

${ }^{48}$ Article cited above, p. 72

49 M. Totoni, E folmja e Bregdetit të Poshtëm, SF, 1, 1964, p. 137

${ }^{50}$ The same place

51 The same place

${ }^{52}$ The same place

53 This form is obtained through assimilation
} 
language which retains many old units and forms of the Albanian language drawing our attention to its purity and originality.

\section{REFERENCES}

[1] M. Totoni, Vëzhgime rreth qytetit të Gjirokastrës, SF, nr.1, 1966.

[2] Q.Haxhihasani, Vështrim i përgjithshëm mbi të folmen e banorëve të Çamërisë, "Dialektologjia shqiptare" vëll. 1, Tiranë, 1971.

[3] M. Kore, "Gjirokastra vështrim historik, gjuhësor, etnologjik", Tiranë, 2014.

[4] M. Totoni, Vëzhgime rreth të folmeve të Kurveleshit, DSH I, Tiranë, 1971.

[5] M. Totoni, E folmja e Bregdetit të Poshtëm, SF, 1, 1964.

[6] M. Totoni, Vëzhgime për të folmen e Muzinës, "SF", 3, 1965.

[7] H. Pedersen, Albanesische texte, Mit glossar, Leipzig, 1895.

\section{AUTHOR'S BIOGRAPHY}

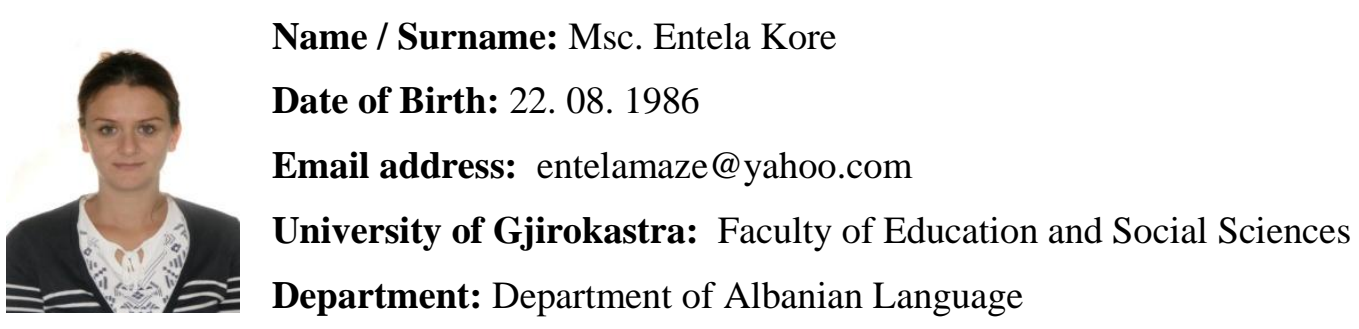

Teaching subject / Field of study (for staff of institutes or research centers) Teaching subject:

Methodology of teaching, History of world language and Academic writing.

Scope of study: General linguistic

Undergraduate Studies: University of Tirana, Faculty of History and Philology,

Branch: Albanian Language and Literature, Period of study: 09.10.2005-17.07.2008

Postgraduate Studies: University of Tirana, Faculty of History and Philology, Direction: Historical Language; Theme: Phonetic and morphological features in the Cham dialect, Leader: Prof. dr. Kolec Topalli, Period: 13.10.2008-09.07.2010

PHD / Doctor of Science: $\mathrm{In} \mathrm{PhD}$ thesis

Citation: Msc. Entela Kore. "Common Features between the Cham Dialect and Other Albanian Dialects" International Journal of Humanities Social Sciences and Education (IJHSSE), vol 5, no. 9, 2018, pp. 138-144. doi: http://dx.doi.org/10.20431/2349-0381.0509019.

Copyright: (C) 2018 Authors. This is an open-access article distributed under the terms of the Creative Commons Attribution License, which permits unrestricted use, distribution, and reproduction in any medium, provided the original author and source are credited. 